\title{
Preoperative Diagnosis of Thyroglossal Duct Cancer: A Case Report and Literature Review
}

\author{
Ai Suzuki'1,2, Kazumasa Suzuki², Yoshiaki Mori², Yoshifumi Fujita², Takashi Hatano², \\ Nobuhiko Oridate ${ }^{3}$ \\ ${ }^{1}$ Department of Otorhinolaryngology, Yokosuka City Hospital, Yokosuka, Japan \\ ${ }^{2}$ Department of Otorhinolaryngology, Yokosuka Kyosai Hospital, Yokosuka, Japan \\ ${ }^{3}$ Department of Otorhinolaryngology-Head and Neck Surgery, Yokohama City University School of Medicine, \\ Yokosuka, Japan \\ Email: aisuzu@jadecom.jp
}

Received 23 March 2015; accepted 13 April 2015; published 17 April 2015

Copyright (C) 2015 by authors and Scientific Research Publishing Inc.

This work is licensed under the Creative Commons Attribution International License (CC BY). http://creativecommons.org/licenses/by/4.0/

(c) (i) Open Access

\section{Abstract}

Objective: To clarify the preoperative diagnostic rate and elucidate the morphological features of thyroglossal duct cancer through a literature search on cases reported in Japan. Methods: A search of a medical database (Japan Medical Abstracts Society) identified 40 studies on thyroglossal duct cancer in Japanese patients between 1976 and 2014. A total of 47 cases, including the present case, are summarized herein. Patient characteristics, preoperative diagnosis, and morphological features were reviewed and analyzed. Morphological features of the internal portions in the cystic lesions were classified using the previously reported Yokosuka Kyosai Hospital criteria for ultrasonography findings of thyroid cystic tumors. Results: Preoperative diagnosis was described for 43 of the 47 cases. Malignancy was suspected in $18(41.9 \%)$ of the 43 cases on the basis of fine needle aspiration (FNA) cytology (presence of suspected papillary carcinoma cells) and imaging studies (presence of calcifications), 12 and 6 cases, respectively. Preoperative FNA was performed in 24 cases with a correct diagnosis obtained in only $12(50 \%)$ cases. Morphological features were evaluated by preoperative imaging studies and/or postoperative histopathology. We found 6 cases $(15 \%)$ with solid lesions, 32 cases $(80 \%)$ with cystic lesions containing a solid part, and 2 cases $(5 \%)$ with solo cystic lesions, respectively. Calcification was observed in $28(72.5 \%)$ cases. We further examined the internal morphology of 32 cases with cystic lesions according to the criteria for ultrasonography findings of thyroid cystic tumors described in Methods. Of the 32 cases, $25(62.5 \%)$ and 7 $(17.5 \%)$ were classified as "eccentric acute angle type (Ea)" and "multiseptate type (M)", respectively. The boundary between the solid part and the cystic part was irregular in all 7 " $M$ " cases. No "eccentric and blunt angle type (Eb)" or "concentric type (C)" lesions were observed. Conclusions: The preoperative diagnostic rate for thyroglossal duct cancer using FNA is low, and it is important that diagnosis be performed in conjunction with imaging findings. The presence of solid parts or calcified lesions classified as "Ea" or " $M$ with irregular boundaries" on the basis of imaging findings 
is suggestive of malignancy.

Keywords

Thyroglossal Duct Cancer, Thyroglossal Duct Cyst, Preoperative Diagnosis

\section{Introduction}

Thyroglossal duct cysts are thought to arise from remnants of the thyroglossal duct, and develop together with the growth of the thyroid gland. Despite rare, cancer is known to be comorbid with thyroglossal duct cysts, with a reported frequency of $1 \%-2 \%$ [1]-[3]. As the clinical presentation of thyroglossal duct carcinomas is often similar to that of benign cysts, a preoperative diagnosis is difficult to obtain. In fact, there are many reports of cancer being histopathologically diagnosed for the first time from a resected specimen [4]-[7]. We experienced such a case of thyroglossal duct cancer. The aim of this study was to perform a literature search on cases reported in Japan to clarify the preoperative diagnostic rate and elucidate the morphological features of thyroglossal duct cancer. We further examined the internal morphology of cystic lesions, according to previously reported criteria for ultrasonography findings of thyroid cystic tumors [8].

\section{Patients and Methods}

A search of a medical database (Japan Medical Abstracts Society) identified 40 studies on thyroglossal duct cancer published by Japanese researchers between 1976 and 2014. A total of 47 cases, including the present case, are summarized in Table 1 [3]-[7] [9]-[43]. Patient characteristics, preoperative diagnosis, and morphological features were reviewed and analyzed.

Morphological features of the internal portions of the cystic lesions were classified using the Yokosuka Kyosai Hospital criteria for the ultrasonography findings of thyroid cystic tumors [8]. Briefly, thyroid gland carcinomas are divided into solid and cystic tumors. Solid tumors are tumors without any cystic part. Cystic tumors include tumors in which a cystic part is observed by ultrasonography studies and are classified as follows. Cases in which the solid part is eccentrically located on the tumor wall are referred to as "eccentric type (E)". This type is further divided into cases in which the angle made by the solid part and the tumor wall is less than 90 degrees, "eccentric acute angle type (Ea)", and those for which the angle is more than 90 degrees, "eccentric and blunt angle type (Eb)". Cases in which the cystic part is in the center of the tumor are referred to as "concentric type (C)", and cases with multiple septa are classified as "multiseptate type (M)" (Table 2).

\section{Results}

\subsection{Case Report}

A 48-year-old woman presented to the Yokosuka Kyosai Hospital with a neck mass that had persisted for one month. She was otherwise asymptomatic. She did not have thyroid disease or radioiodine exposure previously. A smooth rubbery mass of $2 \mathrm{~cm}$ in diameter was located on the right ala of the thyroid cartilage. The mass was not tender and its vertical mobility on deglutition was not limited. Ultrasonography of the neck showed a welldefined hypoechoic lesion with posterior enhancement (Figure 1), but no cervical lymphadenopathy. The thyroid gland did not contain a nodule and seemed completely normal. A Computed tomography (CT) scan showed a $25 \times 18 \times 15 \mathrm{~mm}$ cystic mass on the thyroid cartilage, containing a $5 \times 4 \times 6 \mathrm{~mm}$ solid part with microcalcifications (Figure 2). Fine needle aspiration (FNA) was performed and approximately $2 \mathrm{ml}$ of thin light-yellow fluid was obtained. Cytology did not provide a diagnosis in spite of the presence of some epithelial cells with irregular nuclei. FNA was not repeated because we thought the diagnosis was thyroglossal cyst. Routine blood investigations including free T3, free T4 and TSH were within normal limits.

Under a preoperative diagnosis of thyroglossal duct cyst, an excision of the mass using the method described by Sistrunk was planned. The tumor mass was enucleated with no evident thyroglossal duct in the direction of the hyoid bone. Pathological examination revealed a papillary thyroid carcinoma in a small papillary excrescence within the cystic lumen of the mass. Normal epithelium and ectoic thyroid tissue without malignancy were 
Table 1. Thyroglossal duct cancer cases reported in the Japanese literature.

\begin{tabular}{|c|c|c|c|c|c|c|c|c|c|c|c|}
\hline Case & Age & Sex & $\begin{array}{l}\text { Morphology } \\
\text { of tumor }\end{array}$ & Calc. & $\begin{array}{c}\text { FNA } \\
\text { cytology }\end{array}$ & $\begin{array}{c}\text { Preoperative } \\
\text { diagnosis }\end{array}$ & LNM & Thyroid ca. & Histology & Year reported & Author \\
\hline 1 & 66 & $\mathrm{~F}$ & $\mathrm{Ea}$ & - & 1 & 1 & + & - & $\mathrm{P}$ & 1976 & Nagamine \\
\hline 2 & 38 & $\mathrm{~F}$ & Solid & - & I & Benign & - & - & $\mathrm{P}$ & 1977 & Izuo \\
\hline 3 & 23 & $\mathrm{~F}$ & I & + & I & Benign & - & - & $\mathrm{P}$ & 1977 & Inuyama \\
\hline 4 & 43 & $\mathrm{M}$ & M Irreg & + & l & Benign & - & - & $\mathrm{P}$ & 1979 & Marubayashi \\
\hline 5 & 56 & $\mathrm{~F}$ & $\mathrm{Ea}$ & - & l & Benign & - & - & $\mathrm{P}$ & \multirow{3}{*}{1981} & \multirow{3}{*}{ Kinosita } \\
\hline 6 & 48 & $\mathrm{~F}$ & M Irreg & + & I & Benign & - & - & $P$ & & \\
\hline 7 & 25 & $\mathrm{~F}$ & l & l & l & Benign & I & 1 & $\mathrm{P}$ & & \\
\hline 8 & 25 & $\mathrm{~F}$ & l & l & Malignant & Malignant & + & l & $\mathrm{P}$ & \multirow[t]{2}{*}{1983} & \multirow[t]{2}{*}{ Hanamatsu } \\
\hline 9 & 38 & $\mathrm{M}$ & l & I & I & Benign & l & I & $\mathrm{P}$ & & \\
\hline 10 & 30 & $\mathrm{~F}$ & $\mathrm{Ea}$ & - & Malignant & Malignant & + & - & $P$ & 1985 & Tanaka \\
\hline 11 & 55 & $\mathrm{M}$ & $\mathrm{Ea}$ & I & I & 1 & - & - & $P$ & 1986 & Hirabuki \\
\hline 12 & 37 & $\mathrm{M}$ & Cyst & + & I & Benign & + & - & $\mathrm{P}$ & 1986 & Nagasawa \\
\hline 13 & 35 & $\mathrm{~F}$ & I & + & I & Benign & - & - & $\mathrm{P}$ & 1988 & Takahasi \\
\hline 14 & 24 & $\mathrm{~F}$ & M Irreg & + & I & Benign & - & - & $P$ & 1989 & Ymasoba \\
\hline 15 & 67 & $\mathrm{~F}$ & $\mathrm{Ea}$ & + & I & Malignant & - & - & $P$ & 1989 & Mituyama \\
\hline 16 & 61 & $\mathrm{~F}$ & $\mathrm{Ea}$ & - & Benign & Benign & - & - & $\mathrm{P}$ & 1990 & Takeuti \\
\hline 17 & 22 & $\mathrm{M}$ & $\mathrm{Ea}$ & + & l & Benign & - & - & $\mathrm{P}$ & 1991 & Kobayashi \\
\hline 18 & 17 & $\mathrm{~F}$ & M Irreg & + & I & Benign & - & - & $\mathrm{P}$ & 1993 & Hurukawa \\
\hline 19 & 42 & $\mathrm{M}$ & $\mathrm{Ea}$ & + & Benign & Benign & - & - & $\mathrm{P}$ & 1993 & Takeuti \\
\hline 20 & 58 & $\mathrm{~F}$ & $\mathrm{Ea}$ & + & Malignant & Malignant & - & - & $\mathrm{P}$ & 1994 & Hoshino \\
\hline 21 & 37 & $\mathrm{~F}$ & $\mathrm{Ea}$ & - & Benign & Benign & - & - & $\mathrm{P}$ & 1995 & Taketani \\
\hline 22 & 67 & $\mathrm{~F}$ & M Irreg & + & Malignant & Malignant & + & - & $\mathrm{P}$ & 1995 & Hoshida \\
\hline 23 & 28 & $\mathrm{~F}$ & $\mathrm{Ea}$ & + & I & Benign & - & - & $\mathrm{P}$ & 1995 & Masuda \\
\hline 24 & 64 & $\mathrm{~F}$ & M Irreg & + & Malignant & Malignant & + & - & $P$ & 1996 & Ohtsuki \\
\hline 25 & 33 & $\mathrm{M}$ & l & + & I & I & - & + & $\mathrm{P}$ & 1997 & Imai \\
\hline 26 & 70 & $\mathrm{~F}$ & Solid & - & Malignant & Malignant & - & - & $\mathrm{P}$ & 1998 & Kitajiri \\
\hline 27 & 17 & $\mathrm{M}$ & $\mathrm{Ea}$ & + & Benign & Malignant & - & - & $P$ & 1998 & Simamoto \\
\hline 28 & 55 & $\mathrm{~F}$ & $\mathrm{Ea}$ & + & Benign & Malignant & - & + & $\mathrm{P}$ & 1999 & Yamamoto \\
\hline 29 & 47 & $\mathrm{~F}$ & $\mathrm{Ea}$ & + & Benign & Malignant & - & - & $\mathrm{P}$ & 2000 & Ikejiri \\
\hline 30 & 77 & $\mathrm{M}$ & $\mathrm{Ea}$ & + & Benign & Malignant & - & - & $\mathrm{P}$ & 2001 & Kusunoki \\
\hline 31 & 26 & $\mathrm{~F}$ & $\mathrm{Ea}$ & + & Benign & Benign & - & - & $\mathrm{P}$ & 2002 & Ohtsuki \\
\hline 32 & 20 & $\mathrm{M}$ & $\mathrm{Ea}$ & + & I & Benign & - & - & $\mathrm{P}$ & 2004 & Okabayashi \\
\hline 33 & 81 & $\mathrm{M}$ & Solid & - & Malignant & Malignant & - & - & $\mathrm{P}$ & 2005 & Hori \\
\hline 34 & 43 & $\mathrm{M}$ & $\mathrm{Ea}$ & + & I & Benign & - & - & $\mathrm{P}$ & 2005 & Sakabe \\
\hline 35 & 54 & $\mathrm{M}$ & M Irreg & + & Malignant & Malignant & - & - & $\mathrm{P}$ & 2006 & Umiyama \\
\hline 36 & 32 & $\mathrm{~F}$ & $\mathrm{Ea}$ & + & Malignant & Malignant & - & - & $\mathrm{P}$ & 2008 & Kajikawa \\
\hline 37 & 63 & $\mathrm{M}$ & $\mathrm{Ea}$ & + & I & Benign & + & + & $P$ & \multirow{4}{*}{2008} & \multirow{4}{*}{ Sato } \\
\hline 38 & 59 & $\mathrm{~F}$ & $\mathrm{Ea}$ & + & Benign & Benign & + & + & $\mathrm{P}$ & & \\
\hline 39 & 36 & $\mathrm{M}$ & $\mathrm{Ea}$ & I & Malignant & Malignant & + & + & $\mathrm{P}$ & & \\
\hline 40 & 63 & $\mathrm{M}$ & Cyst & - & Malignant & Malignant & - & - & $P$ & & \\
\hline 41 & 59 & $\mathrm{M}$ & Solid & I & Benign & Benign & I & I & $\mathrm{P}$ & 2008 & Sakamoto \\
\hline 42 & 48 & $\mathrm{M}$ & $\mathrm{Ea}$ & + & Benign & Malignant & I & I & $\mathrm{P}$ & 2010 & Kadokawa \\
\hline 43 & 30 & $\mathrm{~F}$ & Solid & - & Malignant & Malignant & - & - & $\mathrm{P}$ & 2013 & Uemura \\
\hline 44 & 38 & $\mathrm{~F}$ & $\mathrm{Ea}$ & + & Insufficient & Benign & - & - & $\mathrm{P}$ & 2013 & Present case \\
\hline 45 & 43 & $\mathrm{~F}$ & I & I & I & Benign & - & + & F & 1982 & Suzuki \\
\hline 46 & 75 & $\mathrm{~F}$ & Solid & - & I & Benign & - & - & $\mathrm{F}$ & 1996 & Otsuka \\
\hline 47 & 50 & $\mathrm{~F}$ & I & I & I & I & I & I & $\mathrm{S}$ & 1992 & Simizu \\
\hline
\end{tabular}

/: Not described; Calc.: Calcification; LNM: Lymph node metastasis; Thyroid ca.: Thyroid carcinoma; Ea: Eccentric and acute angle type; M Ireg: Multiseptate type case and that showed irregular boundaries between the solid part and the cystic part; P: Papillary adenocarcinoma; F: Follicular carcinoma; S: Squamous cell carcinoma. 
Table 2. The typing of ultrasonography findings of thyroid cystic tumors.

Eccentric type
$\begin{aligned} & \text { Cases in which the solid part is eccentrically } \\ & \text { located on the tumor wall. }\end{aligned}$

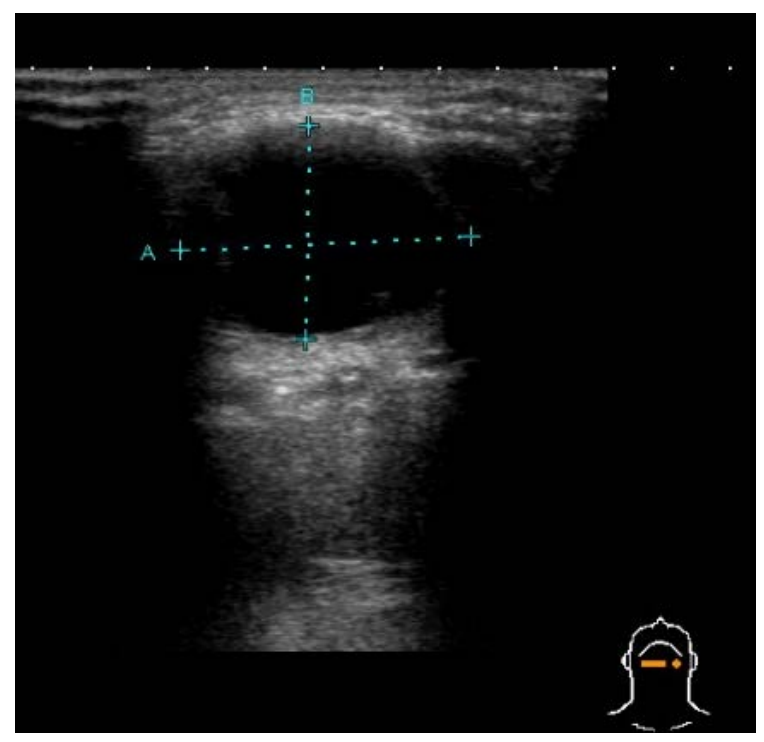

Figure 1. Ultrasonography of the neck.

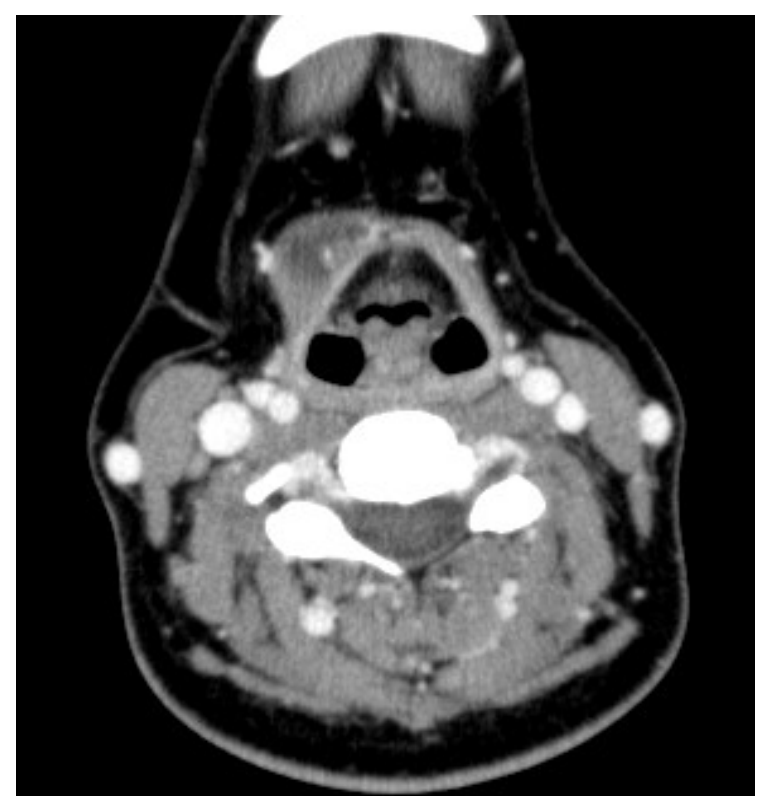

Figure 2. Computed tomography. A $5 \times 4 \times 6 \mathrm{~mm}$ solid part and microcalcifications (arrow) were observed on the head of the tumor. 
also identified within the cyst. The surgical margin was negative. Additional surgery was not undertaken because of the negative surgical margin and absence of a thyroid nodule. The patient remained disease-free for two years and nine months after the surgery.

\subsection{Previously Reported Cases of Thyroglossal Duct Cancer in Japan}

The studies reported 18 male and 29 female patients, with ages ranging from 17 to 81 years (median: 43 years). There were 44 cases of papillary carcinoma, two cases of follicular carcinoma, and one case of squamous cell carcinoma. Lymph node involvement was observed in 9 (21.4\%) of the 42 cases with description of lymph node involvement, and carcinoma in the thyroid gland was found in $6(14.6 \%)$ of 41 cases with description of comorbidity. Preoperative diagnosis was reported in 43 of the 47 cases. Malignancy was suspected in $18(41.9 \%)$ of these 43 cases on the basis of FNA cytology (presence of suspected papillary carcinoma cells) and imaging studies (presence of calcifications) in 12 and 6 cases, respectively. Preoperative FNA was performed in 24 cases, with a correct diagnosis obtained in only $12(50 \%)$ cases.

\subsection{Morphological Features of the Internal Portions of the Cystic Lesions for Cases Previously Reported in Japan}

As the diagnostic accuracy of FNA cytology for thyroglossal duct cancer is not as high as that for papillary thyroid carcinoma, we speculated that preoperative imaging findings would be important for the preoperative diagnosis of thyroglossal duct cancer. We, therefore, investigated the morphological features of the internal portions of the cystic lesions. In 40 of the above 47 cases (including the present case), these features could be evaluated by the preoperative imaging studies and/or postoperative histopathology. We found 6 cases (15\%) with solid lesions, 32 cases $(80 \%)$ with cystic lesions containing a solid part, and 2 cases $(5 \%)$ with solo cystic lesions. Calcification was observed in 28 (72.5\%) cases. We further examined the internal morphology of the 32 cases with cystic lesions according to the criteria for ultrasonography findings of thyroid cystic tumors described in Methods 8). Of the 32 cases, $25(62.5 \%)$ and 7 (17.5\%) were classified as "Ea" and "M", respectively. The boundary between the solid part and the cystic part was irregular in all 7 "M" cases. No "Eb" or "C" lesions were observed.

\section{Discussion}

Pre-operative evaluation of lesions suspected of being thyroglossal duct cysts consists of ultrasonography, CT scans, magnetic resonance imaging (MRI), and FNA cytology. As the clinical presentation of thyroglossal duct carcinoma is often similar to that of benign cysts, these examinations have been indicated for patients with thyroglossal duct carcinomaas well.

However, a preoperative diagnosis is difficult to obtain even after these examinations and the diagnosis of malignancy is often obtained postoperatively from histopathology reports. In this study population, malignancy was suspected in only $18(41.9 \%)$ of the 43 cases for which a preoperative diagnosis was given. This low preoperative diagnostic rate for thyroglossal duct cancer is primarily due to the low correct diagnostic rate of FNA cytology.

It has been reported that the diagnostic rate of FNA cytology for this disease is $50 \%-60 \%$, which is lower than that for ordinary thyroid gland cancer [4]. FNA cytology can be readily diagnostic as long as enough material is obtained, and FNA cytology has led to a pre-operative diagnosis of malignancy in $50 \%$ of our patient cohort. On the other hand, in cystic lesions where tumor cells are confined to the wall, it may be difficult to obtain enough cells to reach a correct diagnosis. Ultrasonography guided FNA may be useful in such cases. Repeating FNA after the cystic contents have been aspirated may also be more diagnostic.

We speculated that preoperative imaging findings are important in increasing the preoperative diagnostic rate for thyroglossal duct cancer and, therefore, investigated the morphological features of this disease. It has been reported that the identification of calcified lesions or solid parts in imaging findings is suggestive of malignancy [4] [7]. In our series of patients, calcifications and lesions containing solid parts were observed in $28(72.5 \%)$ and $38(95 \%)$ cases, respectively. On the other hand, it has been reported that either solid parts or calcified lesions were absent in benign thyroglossal duct cysts examined by ultrasonography [44]-[46].

However, not all cases of thyroglossal duct cyst necessarily present with typical ultrasonography findings (i.e., thin walls and no internal echoes). There are cases in which the cysts exhibit various kinds of internal echoes or 
wall thickening due to intracystic inflammation or proteins discharged from the epithelial cells of the cyst wall [44]-[46]. In some of these cases, partial thickening of the wall of more than $5 \mathrm{~mm}$ was observed [44] and this wall thickening might have been mistaken for a solid part.

In this study, we further examined the internal morphology of 32 cases with cystic lesions, according to the criteria for ultrasonography findings of thyroid cystic tumors described in Methods [8]. In our previous report summarizing the ultrasonography findings of operations for thyroid cystic tumors in Yokosuka Kyosai Hospital [8], we found a significant number of "Ea" malignant tumors. In addition, malignancy was also suggested in "Eb" lesions in which the solid part accounted for over $50 \%$ of the tumor mass, and in "M" lesions that showed irregular boundaries between the solid part and the cystic part. In this series of patients, all 32 cases with cystic lesions containing a solid part were classified as either "Ea" (25/32) or "M with irregular boundaries" between the solid part and the cystic part (7/32).

An incorrect diagnosis is thought likely to occur when a thickened wall is mistaken for a solid part, particularly in thyroglossal duct cysts with a partial thickened wall of more than $5 \mathrm{~mm}$ [44], which might be classified as "Eb" or "C" according to the criteria used. Therefore, we concluded that only a finding of "Ea" or "M with irregular boundaries" should be considered suggestive of malignancy in thyroglossal duct cysts.

We observed 2 cases in which the cysts did not contain solid part (Case 12 and 40). [16] [37] Preoperative diagnosis of thyroglossal duct cyst was obtained from ultrasonography examination for Case 12 and from MRI for Case 40. The existence of intracystic papillary cancer and normal thyroid gland tissue are described in both sets of postoperative histopathological results, suggesting the possibility that small solid lesions could be missed in the preoperative imaging examinations. This possibility was estimated to be $5 \%$ in this study.

\section{Conclusion}

The preoperative diagnostic rate for thyroglossal duct cancer using FNA is low, and it is important that diagnosis be performed in conjunction with imaging findings. The presence of solid parts or calcified lesions in lesions that are classified as "Ea" or "M with irregular boundaries" on the basis of imaging findings is suggestive of malignancy.

\section{References}

[1] Keeling, J.H. and Ochsner, A. (1959) Carcinoma in Thyroglossal Duct Remnants. Review of Literature and Report of 2 Cases. Cancer, 12, 596-600. http://dx.doi.org/10.1002/1097-0142(195905/06)12:3<596::AID-CNCR2820120319>3.0.CO;2-2

[2] Livolsi, V.A., Perzin, K.H. and Savetsky, L. (1974) Carcinoma Arising in Median Ectopic Thyroid (Including Thyroglossal Duct Tissue). Cancer, 34, 1303-1315. http://dx.doi.org/10.1002/1097-0142(197410)34:4<1303::AID-CNCR2820340442>3.0.CO;2-S

[3] Nagamine, N., Miyazaki, Y. and Syo, Y. (1976) A Case of a Carcinoma Arising from a Thyroglossal Duct Remnant: Report of a Case with a Review of the Literature. Japanese Journal of Cancer Clinics, 22, 793-797.

[4] Shimamoto, K., Sugimoto, T., Noguchi, Y., Negishi, T., Haraguchi, H. and Komatsuzaki, A. (1998) A Case of Carcinoma Arising in a Thyroglossal Duct Remnant. Practica Otologica, 91, 937-944. http://dx.doi.org/10.5631/jibirin.91.937

[5] Yamamoto, K., Haji, T. and Tanaka, A. (1999) The Case of a Carcinoma Arising from a Thyroglossal Duct Remnant with a Thyroid Papillary Carcinoma. Practica Otologica, 92, 773-777. http://dx.doi.org/10.5631/jibirin.92.773

[6] Kusunoki, T., Okita, A., Nishida, S., Tanaka, Y. and Murata, K. (2001) A Case of Carcinoma Arising from a Thyroglossal Duct Remnant with Difficulty Discrimination. Practica Otologica, 94, 173-178. http://dx.doi.org/10.5631/jibirin.94.173

[7] Sakabe, A., Udaka, T., Hiraki, N., Wakasugi, T., Kitamura, T. and Tokui, N. (2005) A Case of Papillary Carcinoma Arising from Thyroglossal Duct Cyst. Practica Otologica, 98, 61-65. http://dx.doi.org/10.5631/jibirin.98.61

[8] Komatsu, A., Suzuki, K. and Fujita, Y. (2013) Preoperation Diagnosis of Cystic Thyroid Nodules. Head and Neck Cancer (in Japanese), 39, 77-82. http://dx.doi.org/10.5981/jjhnc.39.77

[9] Izuo, M., Kawai, T., Kusaba, T., Satoh, K., Kaneko, H., Hosono, O., Satoh, H., Ishida, T. and Azuma, Y. (1977) Report of a Case of a Carcinoma Arising from a Thyroglossal Duct Remnant with a Review of the Literature. Japanese Journal of Cancer Clinics, 23, 546-549.

[10] Inuyama, S., Takahashi, K., Ozu, R., Kawashiro, N. and Inuyama, Y. (1977) Papillary Adenocarcinoma Arising from 
the Remnants of the Thyroglossal Duct. Otorhinolaryngology, 49, 653-657.

[11] Marubayashi, S., Aoki, Y., Tanaka, I., Dohi, K., Kodama, M. and Ezaki, H. (1979) A Case of a Carcinoma Arising from a Thyroglossal Duct Remnant. Japanese Journal of Cancer Clinics, 25, 1333-1335.

[12] Kinoshita, Y., Kamata, H., Kurozu, T., Honma, Y., Kobayashi, S., Shimura, K. and Komori, A. (1981) Carcinoma Arising in Thyroglossal Duct Remnant: Report of Two Cases with a Review of the Literature. Journal of Oral and Maxillofacial Surgery, 27, 117-124.

[13] Hanamatsu, M., Kaneda, I., Ogawa, H., Takahashi, S. and Kurihara, H. (1983) The Three Cases of Papillary Carcinoma Arising from Thyroglossal Duct Cyst. Journal of Clinical Surgery, 38, 1253-1256.

[14] Tanaka, H., Okuno, M., Ohkita, H., Yamashita, T., Umeyama, K. and Sugano, S. (1985) A Case Report of Papillary Carcinoma Arising on a Thyroglossal Duct Remnant and a Review of the Literature. Journal of the Japanese Practical Surgeon Society, 46, 346-353. http://dx.doi.org/10.3919/ringe1963.46.346

[15] Hirabuki, N., Maruyama, T., Arisawa, J., Mitomo, M., Kuroda, C., Taya, N. and Yamashita, K. (1986) Papillary Carcinoma Arising from Thyroglossal Duct Remnant. Clinical Radiology, 31, 531-533.

[16] Nagasawa, A., Yajin, K., Shirane, M., Ohuchi, Y., Takano, A. and Hirata, S. (1986) Papillary Adenocarcinoma of a Thyroglossal Duct Cyst. Practica Oto-Rhino-Laryngologica, 79, 1117-1125. http://dx.doi.org/10.5631/jibirin.79.1117

[17] Takahashi, M., Noguchi, I., Sato, Y., Ando, T., Hayama, S., Kurokawa, H., Kaneko, T., Yanada, Y., Ichihara, Y. and Usuki, S. (1988) A Case Report of Papillary Carcinoma Arising from a Thyroglossal Duct Cyst. Japanese Journal of Oral and Maxillofacial Surgery, 34, 43-44.

[18] Yamasoba, T., Tanaka, T. and Takahashi, A. (1989) A Case Report of Papillary Carcinoma Arising from a Thyroglossal Duct Remnant. Otolaryngology-Head and Neck Surgery (Tokyo), 61, 455-460.

[19] Mitsuyama, S., Nakamura, Y., Toyoshima, S. and Ito, J. (1989) A Case Report of Papillary Carcinoma Arising from a Thyroglossal Duct Remnant. Surgical Diagnosis \& Treatment, 31, 1537-1542.

[20] Takeuchi, K., Mukawa, K., Kato, R., Koitabashi, H., Nishida, Y. and Nagamachi, Y. (1990) A Case Report of Papillary Carcinoma Arising from a Thyroglossal Duct Remnant. Surgical Diagnosis \& Treatment, 32, 865-869.

[21] Kobayashi, T., Murakami, S., Takasuka, N., Furuya, K., Tao, S. and Kitani, S. (1991) Papillary Adenocarcinoma of the Thyroglossal Duct. Ehime Medical Journal, 10, 110-115.

[22] Furukawa, T., Kitahara, S., Ikeda, M., Terahata, S., Tabe, T., Ogura, M. and Inouye, T. (1993) Papillary Carcinoma in a Remnant of the Thyroglossal Duct. Nihon Kikan Shokudoka Gakkai Kaiho, 44, 239-243. http://dx.doi.org/10.2468/jbes.44.239

[23] Takeuchi, S., Kawata, I., Takeda, J., Arisawa, Y., Kashima, K., Kosai, M., Kondo, A. and Tadhibana, F. (1993) A Case of Carcinoma Arising from the Thyroglossal Duct Remnant. Practica Oto-Rhino-Laryngologica, Supple 61, 225-229. http://dx.doi.org/10.5631/jibirinsuppl1986.1993.Supplement61_225

[24] Hoshino, N., Sugiuchi, T., Okamoto, Y., Zusho, H. and Eguchi, M. (1994) Carcinoma Arising in Thyroglossal Duct Remnant: A Case Report and Review of the Literature. Oto-Rhino-Laryngology, Tokyo, 37, 649-655.

[25] Taketani, S., Yoshikawa, K., Hashimoto, T., Yamaguchi, T., Dousei, T., Moriguchi, A., Taniguchi, M., Ueda, H., Utsumi, A., Suhara, H., et al. (1995) A Case Report of Ectopic Thyroid Cancer Originated from the Thyroglossal Duct Remnant. Journal of the Japanese Practical Surgeon Society, 56, 948-952. http://dx.doi.org/10.3919/ringe1963.56.948

[26] Hoshida, Y., Haratome, S., Yamashita, N., Murakami, I., Miyake, K., Miyata, K. and Yoshino, T. (1995) A Case Thyroglossal Duct Carcinoma Diagnosed by Fine Needle Aspiration Cytology. Journal of the Japanese Society of Clinical Cytology, 34, 692-697.

[27] Masuda, M., Makishima, T., Toriya, Y., Toyoshima, S. and Komiyama, S. (1995) A Case of Papillary Carcinoma Arising in Thyroglossal Duct Cyst. Otologia Fukuoka, 41, 752-756.

[28] Ohtsuki, Y., Manabe, S., Iwata, J., Sonobe, H., Okada, Y., Sudo, S. and Ohmori, K. (1996) A Case of Thyroglossal Duct Cyst Combined with Papillary Carcinoma. Journal of the Japanese Society of Clinical Cytology, 35, 451-455. http://dx.doi.org/10.5795/jissc. 35.451

[29] Imai, Y., Takahashi, K., Yoshihara, T. and Ishi, T. (1997) A Case Report of Papillary Carcinoma Arising from a Thyroglossal Duct Remnant. Otolaryngology-Head and Neck Surgery (Tokyo), 69, 318-321.

[30] Kitajiri, S., Kaneko, K., Shoji, K., Kojima, H. and Asato, R. (1998) A Papillary Carcinoma Arising from the Thyroglossal Duct Remnant; A Case Report. Practica Oto-Rhino-Laryngologica, 91, 715-719. http://dx.doi.org/10.5631/jibirin.91.715

[31] Ikejiri, K., Takeshita, M., Saitsu, H., Yakabe, S., Nonaka, M., Saku, M. and Yoshida, K. (2000) Papillary Thyroid Carcinoma Arising in a Thyroglossal Duct Cyst: Report of a Case and Review of the Literature. Endocrine Surgery, 17, 295-298.

[32] Ohtsuki, N. and Kumoi, K. (2002) Papillary Carcinoma Arising in the Thyroglossal Duct Remnant. Journal of Japan 
Society for Head and Neck Surgery, 12, 85-88. http://dx.doi.org/10.5106/jishns.12.85

[33] Okabayashi, K., Kinoyo, T., Okuda, K., Nishiwaki, S. and Anodo, K. (2004) Case Report of a Papillary Thyroid Carcinoma Arising from a Thyroglossal Duct Cyst. Journal of Japan Surgical Association, 65, 2589-2592.

[34] Hori, R. and Haji, T. (2005) Papillary Carcinoma Arising from the Lateral Branch Remnant of the Thyroglossal Duct. Practica Otologica, 98, 421-425.

[35] Umiyama, T., Watanabe, H., Namba, M., Namba, G. and Suzaki, H. (2006) A Case Report of Papillary Carcinoma Arising from a Thyroglossal Duct Remnant. Otolaryngology-Head and Neck Surgery (Tokyo), 78, 90-91.

[36] Kajikawa, H., Matushiro, N., Kamakura, T., Kitamura, T. and Okumura, S. (2008) A Case of Papillary Carcinoma Arising from Thyroglossal Duct. Journal of Japan Society for Head and Neck Surgery, 18, 259-265. http://dx.doi.org/10.5106/jjshns.18.259

[37] Sato, K. and Takahashi, S. (2008) Clinical Analysis of 4 Cases of Thyroglossal Duct Cyst Papillary Carcinoma. Practica Oto-Rhino-Laryngologica, 101, 479-484. http://dx.doi.org/10.5631/jibirin.101.479

[38] Sakamoto, K., Tomita, T., Imanishi, Y. and Ogawa, K. (2008) Study from Cases-A Malignant Tumor of Head and Neck. A Tumor of Anterior Neck. Journal of Otolaryngology, Head and Neck Surgery, 24, 657-660.

[39] Kadokawa, Y., Shiomori, T., Nagatani, G., Mori, T., Ueda, N., Inaba, T., Wakasugi, T., Ohbuchi, T. and Suzuki, H. (2010) A Case of Thyroglossal Duct Carcinoma and Concomitant Warthin's Parotid Glands Tumors. Practica OtoRhino-Laryngologica, 103, 575-579. http://dx.doi.org/10.5631/jibirin.103.575

[40] Uemura, A., Takahara, M., Nagato, T., Ueda, S., Hayashi, T. and Harabuchi, Y. (2013) A Case of Papillary Carcinoma of the Thyroglossal Duct. Practica Oto-Rhino-Laryngologica, 106, 447-453. http://dx.doi.org/10.5631/jibirin.106.447

[41] Suzuki, S., Taniguchi, S. and Uchida, H. (1982) Report of a Case of Carcinoma Arising in a Thyroglossal Duct Remnant. Practica Oto-Rhino-Laryngologica, 75, 722-727. http://dx.doi.org/10.5631/jibirin.75.2special 722

[42] Otsuka, K., Ikeda, E., Naito, M., Konishi, J., Yamada, M., Moriyama, S., Tsuji, H., Furutani, S., Kawakami, S. and Ono, K. (1996) Follicular Carcinoma Arising in a Thyroglossal Duct Remnant. Journal of Japanese Society for Clinical Surgery, 57, 1585-1588.

[43] Shimizu, K., Kikkawa, A., Uchiyama, K., Ide, M., Shibuya, T. and Shoji, T. (1992) Clinical Features of 23 Operative Cases of Thyroglossal Duct Cysts Including One Squamous Cell Carcinoma with Literature Review. Journal of the Japanese Practical Surgeon Society, 53, 504-509. http://dx.doi.org/10.3919/ringe1963.53.504

[44] Ahuja, A.T., King, A.D., King, W. and Metreweli, C. (1999) Thyroglossal Duct Cysts: Sonographic Appearances in Adults. American Journal of Neuroradiology, 20, 579-582. http://.ajnr.org/content/20/4/579.full.pdf+html

[45] Ahuja, A.T., King, A.D. and Metreweli, C. (2000) Sonographic Evaluation of Thyroglossal Duct Cysts in Children. Clinical Radiology, 55, 770-774. http://dx.doi.org/10.1053/crad.2000.0514

[46] Wadsworth, D.T. and Siegel, M.J. (1994) Thyroglossal Duct Cysts: Variability of Sonographic Findings. American Journal of Roentgenology, 163, 1475-1477. http://dx.doi.org/10.2214/ajr.163.6.7992750 